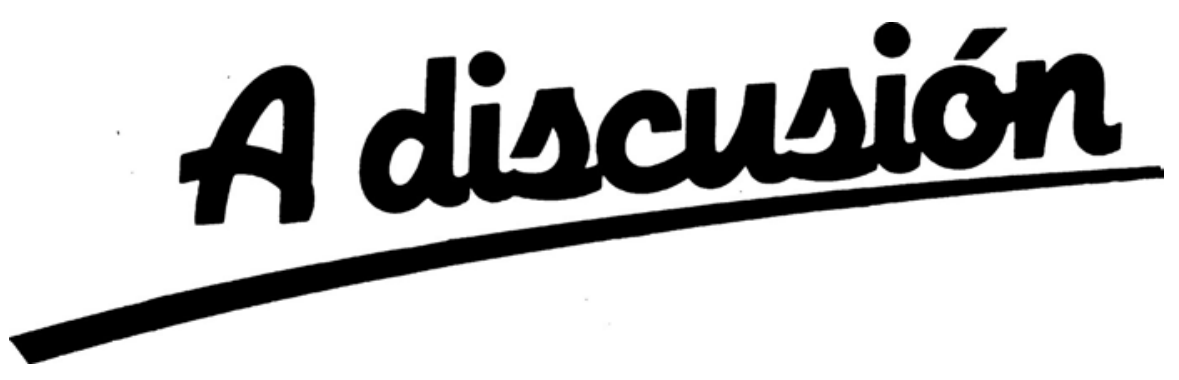

\title{
A MODEL OF UNBALANCED SECTORIAL GROWTH WITH APPLICATION TO TRANSITION ECONOMIES*
}

\section{Dmytro Kylymnyuk, Lilia Maliar and Serguei Maliar**}

\author{
WP-AD 2005-26
}

Corresponding author: L. Maliar. Departamento de Fundamentos del Análisis Económico, Universidad de Alicante, Campus San Vicente del Raspeig, Ap. Correos 99, 03080 Alicante, Spain. E-mail: maliarl@merlin.fae.ua.es.

Editor: Instituto Valenciano de Investigaciones Económicas, S.A.

Primera Edición Septiembre 2005

Depósito Legal: V-3793-2005

IVIE working papers offer in advance the results of economic research under way in order to encourage a discussion process before sending them to scientific journals for their final publication.

* This research was supported by the Instituto Valenciano de Investigaciones Económicas, the EERC Consortium and the Ministerio de Educación, Cultura y Deporte, SEJ2004-08011ECON.

** D. Kylymnyuk: University of Toulouse. L. Maliar and S. Maliar: University of Alicante. 


\title{
A MODEL OF UNBALANCED SECTORIAL GROWTH WITH APPLICATION TO TRANSITION ECONOMIES
}

\author{
Dmytro Kylymnyuk, Lilia Maliar and Serguei Maliar
}

\begin{abstract}
This paper studies the implications of a dynamic general equilibrium model with three production sectors, which are agriculture, industry and services. Due to the assumption of increasing returns in industry and services, our model has multiple equilibria. Two equilibria are stable: one, in which a country produces only agricultural goods and converges to a steady state, and the other, in which a country operates all three sectors and has positive unbalanced long-run growth by contracting agriculture and expanding industry and services. These predictions agree well with the real-world development experiences of rich and poor countries. In the context of our model, we also investigate the evolution of the sectorial composition in the transition countries and find that such countries move to the rich rather than to the poor world.
\end{abstract}

JEL Classification: F10, F12, O13, O30, O41

Keywords: Growth model, Increasing returns to scale, Agriculture, Industry, Services, Multiple equilibria, Transition economies 


\section{Introduction}

This paper studies the implications of a dynamic general equilibrium model with three production sectors, which are agriculture, industry and services. Due to the assumption of increasing returns in industry and services, our model has multiple equilibria. Two equilibria are stable: one, in which a country produces only agricultural goods and converges to a steady state, and the other, in which a country operates all three sectors and has positive unbalanced long-run growth by contracting agriculture and expanding industry and services. These predictions agree well with the real-world development experiences of rich and poor countries. In the context of our model, we also investigate the evolution of the sectorial composition in the transition countries and find that such countries move to the rich rather than to the poor world.

The consumer's side of our economy is standard: a representative consumer solves an intertemporal utility-maximization problem subject to a capital-accumulation constraint. Concerning the producer's side, we assume that the three sectors produce the same output commodity by using different technologies. ${ }^{1}$ All three sectors use capital input, and in addition, the agri-

\footnotetext{
${ }^{1}$ In this assumption, we follow Hansen and Prescott (2000) who assume that the manufactured and agricultural goods are perfect substitutes.
} 
cultural sector uses land input. There are positive spillovers across firms in the sense of Romer (1986). Specifically, we assume that having more capital in industry and services augments productivity of each firm of these sectors. If no firm invests in industry and services, the productivity of these sectors is zero, so that no individual firm has incentives to invest there, unless sufficiently many other firms do so. This is precisely the feature of the model that produces multiplicity of equilibrium: countries whose producers manage to coordinate on opening industry and services become rich, whereas those whose producers did not succeed in doing so remain poor.

There is a body of literature based on multi-sector models with increasing returns to scale, e.g., Murphy, Shleifer and Vishny (1989), Kemp and Schweinberger (1991), Matsuyama (1991, 1992), Rodrik (1996). ${ }^{2}$ This literature explains the differences in patterns of economic development across countries by multiplicity of equilibrium: rich countries are those that are situated in high-income equilibria, while poor countries are those that stick to low-income equilibria. ${ }^{3}$ Two recent contributions to this literature are Eswaran and Kotwal (2002) and Graham and Temple (2003). The former paper extends the standard setup with two sectors, industry and agriculture,

\footnotetext{
${ }^{2}$ See also Choi and $\mathrm{Yu}(2002)$ for a review of the international-trade literature that employes the assumption of increasing returns to scale.

${ }^{3} \mathrm{~A}$ review of the literature on coordination can be found in Rodrik (2003).
} 
to include a third sector, services, and studies the role of the service sector in the process of industrialization. The latter paper calibrates a two-sector model with economies of scale to the data and establishes whether each considered country is situated in a low-income or a high-income equilibrium. ${ }^{4}$

Our paper differs from the above literature in three dimensions. First, our set of assumptions leads to non-vanishing economic growth in a good equilibrium, as opposed to a bad equilibrium, in which there is no long-run growth. In contrast, the assumptions used in previous literature do not admit long-run growth, so that good and bad equilibria differ only in the steady state levels. As a result, our model can account for arbitrary large income differences between rich and poor countries, whereas a calibrated variant of a two-steady-state model produces too small income differences relative to the data, see Graham and Temple (2003). Secondly, we augment the standard two-sector model to include the service sector in a dynamic context, which allows us to focus on time-series patterns of the economic development, while

\footnotetext{
${ }^{4}$ Other related literature can be classified in two groups. One group includes multisector neoclassical growth models, which focus on explaining the time-series behavior of the sectorial composition of one given country (Hansen and Prescott, 2000, and Kongsamut, Rebelo and Xie, 1997); in the absence of a permanent cross-country heterogeneity, these models do not account for the cross-country differences since the equilibrium in a neoclassical growth model is unique. The other group includes dynamic Heckscher-Ohlin models of comparative advantage, which explain the cross-country differences by heterogeneity in preferences and technology (Ventura, 1997), timing of development (Atkeson and Kehoe, 2000), endowment of natural resources (Guilló and Pérez, 2003).
} 
Eswaran and Kotwal (2002) study the role of the service sector in a static context. Finally, to test the model's predictions, we look not only at evidence from the developed and the developing countries, as the previous literature does, but also at recent evidence from the transition countries.

The transition economies are currently undertaking a transformation to market economies, however, it is not clear yet whether they will be transformed to rich or poor market economies. In particular, this is not clear because the transition process was initially accompanied by a severe economic crisis and a dramatic reduction in the living standards. It is therefore an open question where the transition countries transit. Our model predicts multiple solutions and thus, it does not allow us to answer this question on purely theoretical grounds: the transition countries can end up either rich or poor depending on the equilibrium selected. Nonetheless, our model allows us to get the answer on empirical grounds, specifically, we can characterize the good and bad equilibria in the model and check which of them fits the development experiences of the transition countries.

In order to establish the equilibrium prevailing in the transition economies, we trace out the sectorial adjustments taking place in these economies along the transition process. Initially, the transition countries had large agricultural and industrial sectors, and they had small service sector compared to 
the corresponding sectors in the developed countries. Therefore, if the transition countries are in the good equilibrium, we should observe an expansion of the service sector and a contraction of the agricultural and the industrial sectors. In turn, if they are in the bad equilibrium, we should see agricultural growth at expanse of the other two sectors. We find that during the 1990-1999 period, the average output shares of industry and agriculture in the transition group of countries had reduced from $44.3 \%$ to $31.1 \%$ and from $20.0 \%$ to $17.0 \%$, respectively, and the average output share of services had increased from $35.7 \%$ to $51.9 \%$. We therefore conclude that on average, the transition economies are in the good equilibrium. The good-equilibrium pattern is particularly pronounced for the most developed transition countries such as Czech Republic, Estonia, Lithuania, Hungary, Poland and Slovak Republic. For less developed transition countries, the development patterns are not entirely clear. In particular, such countries as Albania, Armenia, Azerbaijan, Kyrgyz Republic, Moldova, Romania, Tajikistan and Uzbekistan had experienced an increase in the output share of agriculture, which corresponds to the bad equilibrium.

The rest of the paper is organized as follows. Section 2 develops the model and defines the equilibrium. Section 3 discusses the model's implications. Section 4 tests the empirical relevance of the model, and finally, Section 5 
concludes.

\section{The model}

In this section, we develop the model and describe the corresponding equilibrium conditions. Time is continuous, and the horizon is infinite, $t \in[0, \infty)$. The consumer's side of the economy consist of a continuum of identical infinitely-lived agents, and the producer's side consists of a continuum of identical production firms. Both the agents and the firms have their names uniformly distributed on a unit interval $[0,1]$, which ensures that variables of the representative agent and the representative firm coincides with the corresponding aggregates.

A representative agent has a period utility function of the Cobb-Douglas type. She solves the standard intertemporal utility-maximization problem:

$$
\max _{c_{t}, K_{t}} \int_{0}^{\infty} e^{-\rho t}\left[\frac{c_{t}^{1-\gamma}-1}{1-\gamma}\right] d t
$$

subject to

$$
\begin{gathered}
\dot{K}_{t}=\left(r_{t}-\delta\right) K_{t}+q_{t} N-c_{t}, \\
\lim _{t \rightarrow \infty}\left[K_{t} e^{-\int_{0}^{t} r_{v} d v}\right]=0,
\end{gathered}
$$

where $K_{0}>0$ is given. Here, $c_{t}$ is consumption; $K_{t}$ and $r_{t}$ are the capital stock and the interest rate, respectively; $N$ and $q_{t}$ are land and its rental 
price, respectively; $\rho>0$ is the discount rate; $\gamma>0$ is the utility function parameter; $\delta \in(0,1]$ is the depreciation rate of capital; and finally, (3) is a no Ponzi game condition. Land does not depreciate over time. Dot over $K_{t}$ represents differentiation with respect to time.

A representative firm is composed of three production units, the agricultural, the industrial and the service ones, which we denote by superscripts $" a ", " i "$ and $" s "$, respectively. ${ }^{5}$ All three units produce the same output commodity but use different technologies. There are two production inputs capital, $k_{t}$, and land, $n_{t}$. We assume that land is used only by the agricultural unit, whereas capital is used by all three units. Therefore, the level of output depends on how the firm distributes capital across its production units. As in Romer (1986), we allow for the presence of learning-by-doing spillovers in the production function. As a result, output of each individual firm also depends on how capital is distributed across the agricultural, the industrial and the service sectors at the aggregate level. Thus, the production function of each firm is

$$
F\left(k_{t}^{a}, k_{t}^{i}, k_{t}^{s}, n_{t}, \Phi_{t}\right)
$$

\footnotetext{
${ }^{5}$ The assumption that each firm can operate in all three sectors is convenient because it allows us to explicitly separate the intertertemporal decision about the total capital stock and the intratemporal decisions about the distribution of the total capital stock across sectors. Equivalently, we could have considered a setup where firms can operate only in one sector and where all investment decisions are made by the consumer.
} 
where $k_{t}^{a}, k_{t}^{i}, k_{t}^{s} \geq 0$ are the capital stocks of the agricultural, the industrial and the service units, respectively; and $\Phi_{t}$ is a set of aggregate variables, which represent spillovers (externalities). For example, $\Phi_{t}$ can be composed of the aggregate capital stocks of the three sectors, $K_{t}^{a}, K_{t}^{i}, K_{t}^{s}$, i.e., $\Phi_{t}=$ $\left\{K_{t}^{a}, K_{t}^{i}, K_{t}^{s}\right\}$. We assume that the production function (4) exhibits constant returns to scale in private inputs and that it is continuous, differentiable and strictly concave.

The firm maximizes the period-by-period profit taking $\Phi_{t}, r_{t}$ and $q_{t}$ as given

$$
\pi_{t} \underset{k_{t}^{a}, k_{t}^{i}, k_{t}^{s}, k_{t}, n_{t}}{=\max _{t}}\left\{F\left(k_{t}^{a}, k_{t}^{i}, k_{t}^{s}, n_{t}, \Phi_{t}\right)-r_{t} k_{t}-q_{t} n_{t}\right\}
$$

subject to

$$
\begin{gathered}
k_{t}^{a}+k_{t}^{i}+k_{t}^{s}=k_{t}, \\
k_{t}^{a}, k_{t}^{i}, k_{t}^{s} \geq 0 .
\end{gathered}
$$

Definition: An equilibrium in the economy $(1)-(7)$ is defined as a sequence for the agent's allocation $\left\{c_{t}, K_{t+1}\right\}_{t=0}^{\infty}$, for prices $\left\{r_{t}, q_{t}\right\}_{t=0}^{\infty}$ and for the firm's allocation $\left\{k_{t}^{a}, k_{t}^{i}, k_{t}^{s}, k_{t}, n_{t}\right\}_{t=0}^{\infty}$ such that given the prices:

(i) $\left\{c_{t}, K_{t+1}\right\}_{t=0}^{\infty}$ solves the utility-maximization problem (1) - (3);

(ii) $\left\{k_{t}^{a}, k_{t}^{i}, k_{t}^{s}, k_{t}, n_{t}\right\}_{t=0}^{\infty}$ solves the profit-maximization problem (5) - (7);

(iii) the representative firm's variables coincide with the corresponding 
aggregates,

$$
k_{t}^{a}=K_{t}^{a}, \quad k_{t}^{i}=K_{t}^{i}, \quad k_{t}^{s}=K_{t}^{s}, \quad k_{t}=K_{t}, \quad n_{t}=N
$$

(iv) all markets clear and the non-negatity constraints are satisfied.

It follows from the utility maximization problem (1) - (3) that the agent's optimal choice satisfies the standard Euler equation

$$
\rho+\gamma \frac{\dot{c_{t}}}{c_{t}}=\left[r_{t}-\delta\right]
$$

Further, the profit-maximization conditions of the firm $(5)-(7)$ are described by the following Kuhn-Tucker conditions

$$
\begin{gathered}
\left(\frac{\partial F}{\partial k_{t}^{x}}-r_{t}\right) k_{t}^{x}=0, \quad k_{t}^{x} \geq 0 \text { for } x \in\{a, i, s\}, \\
\left(\frac{\partial F}{\partial n_{t}}-q_{t}\right) n_{t}=0, \quad n_{t} \geq 0 .
\end{gathered}
$$

In particular, condition (9) implies that if the firm has no capital in a sector, this is because such a sector has a rate of return, which is lower than $r_{t}$. Also, this condition implies that all sectors, in which the amount of capital is positive, have the same rate of return, equal to $r_{t}$.

\section{The model's implications}

In this section, we study the implications of the model of Section 2 under particular assumptions about the production function. We specifically assume 
that (4) takes the form:

$$
A\left(k_{t}^{a}\right)^{\beta} N^{1-\beta}+\left\{E \varphi_{t}^{\mu}\left(k_{t}^{i}\right)^{\mu}+D \varphi_{t}^{\mu}\left(k_{t}^{s}\right)^{\mu}\right\}^{1 / \mu},
$$

where $\mu \in(-\infty, 1), A>0, E>0, D>0, \beta \in(0,1)$ and $\varphi_{t}$ are spillovers such that:

$$
\varphi_{t}=\varphi\left(k_{t}^{i}, k_{t}^{s}\right)=\left(k_{t}^{i}+k_{t}^{s}\right)^{1-\beta} .
$$

This specification is based on two simplifying assumptions. First, capital in both industry and services creates common externalities, and secondly, those common externalities affect productivity of both industry and services in the same manner. While these assumptions are very special and should be treated with caution, they allow us to capture an important feature of actual economies, namely, that industry uses services much more intensively than does agriculture, see Eswaran and Kotwal (2002) for a discussion.

Let us characterize the optimal distribution of capital across sectors under the production function (11). As a first step, we shall compute the marginal productivity of capital in agriculture, industry and services, $r_{t}^{a}, r_{t}^{i}$ and $r_{t}^{s}$, respectively, as well as the rental price of land, $q_{t}$,

$$
\begin{gathered}
r_{t}^{a}=\beta A\left(k_{t}^{a}\right)^{\beta-1} N^{1-\beta}, \\
r_{t}^{i}=E\left(k_{t}^{i}\right)^{\mu-1}\left\{E\left(k_{t}^{i}\right)^{\mu}+D\left(k_{t}^{s}\right)^{\mu}\right\}^{1 / \mu-1}\left(k_{t}^{i}+k_{t}^{s}\right)^{1-\beta},
\end{gathered}
$$




$$
\begin{gathered}
r_{t}^{s}=D\left(k_{t}^{s}\right)^{\mu-1}\left\{E\left(k_{t}^{i}\right)^{\mu}+D\left(k_{t}^{s}\right)^{\mu}\right\}^{1 / \mu-1}\left(k_{t}^{i}+k_{t}^{s}\right)^{1-\beta}, \\
q_{t}=(1-\beta) A\left(k_{t}^{a}\right)^{\beta} N^{-\beta}
\end{gathered}
$$

Let us show that in equilibrium, the firm either invests in both industry and services or it invests in none of them. Indeed, conditions (14) and (15) imply that

$$
\frac{r_{t}^{i}}{r_{t}^{s}}=\frac{E\left(k_{t}^{i}\right)^{\mu-1}}{D\left(k_{t}^{s}\right)^{\mu-1}} .
$$

If the firm has capital in industry, $k_{t}^{i}>0$, but not in services, $k_{t}^{s}=0$, then $\lim _{k_{t}^{s} \rightarrow 0} r_{t}^{i} / r_{t}^{s}=0$; this means that the firm can increase its profit by reinvesting from industry to services, so that we are not in equilibrium. In the same way, if the firm has capital in services, $k_{t}^{s}>0$, but not in industry, $k_{t}^{i}=0$, then $\lim _{k_{t}^{i} \rightarrow 0} r_{t}^{i} / r_{t}^{s}=\infty$; this means that the firm can increase its profit by reinvesting from services to industry, so that again we are not in equilibrium.

If the firm invests in both services and industry, then Kuhn-Tucker condition (9) implies that $r_{t}^{i}=r_{t}^{s}$. This fact together with (14) and (15) means that the ratio of capital stocks in industry and services is constant,

$$
k_{t}^{i}=\left(\frac{D}{E}\right)^{\frac{1}{\mu-1}} k_{t}^{s} .
$$

Let us introduce now a new variable $k_{t}^{h}$, which is the total amount of capital in high-sophistication sectors, such as industry and services, $k_{t}^{h} \equiv k_{t}^{i}+k_{t}^{s}$, as 
opposed to a low-sophistication sector, agriculture. In terms of this variable, we can rewrite (18) as

$$
k_{t}^{i}=\frac{\left(\frac{D}{E}\right)^{\frac{1}{\mu-1}}}{1+\left(\frac{D}{E}\right)^{\frac{1}{\mu-1}}} k_{t}^{h} \quad \text { and } \quad k_{t}^{s}=\frac{1}{1+\left(\frac{D}{E}\right)^{\frac{1}{\mu-1}}} k_{t}^{h} .
$$

Then, the marginal productivity of capital, which is the same for industry and agriculture, can be written as

$$
r_{t}^{h}=B\left(k_{t}^{h}\right)^{1-\beta},
$$

where $B \equiv\left(E^{1 /(1-\mu)}+D^{1 /(1-\mu)}\right)^{\frac{1-\mu}{\mu}}$.

Notice that the assumption of decreasing returns to scale in the agricultural sector ensures that output of this sector is always strictly positive. In fact, at low levels of development, $k_{t} \rightarrow 0$, the marginal productivity of capital in agriculture is higher than that in industry and services, i.e.,

$$
\lim _{k_{t} \rightarrow 0} r_{t}^{a}=\infty, \quad \text { and } \quad \lim _{k_{t} \rightarrow 0} r_{t}^{h}=0
$$

for all $k_{t}^{a}, k_{t}^{h} \geq 0$ satisfying $k_{t}^{a}+k_{t}^{h}=k_{t}$. Thus, we have a corner solution where agriculture attracts all capital, while industry and services are not developed at all, i.e., $k_{t}^{a}=k_{t}$ and $k_{t}^{h}=0$. When the aggregate capital stock becomes large enough, in addition to the corner solution, there is an interior solution, where the aggregate capital is split between the sectors, so that all 
of them have the same marginal productivity of capital,

$$
\beta A\left(k_{t}^{a}\right)^{\beta-1} N^{1-\beta}=B\left(k_{t}^{h}\right)^{1-\beta}=B\left(k_{t}-k_{t}^{a}\right)^{1-\beta} .
$$

Let us compute a threshold level of the aggregate capital under which the industry and the service sectors can be opened. Solving for $k_{t}^{a}$ from (22) yields

$$
k_{t}^{a}=\frac{1}{2}\left[k_{t} \pm \sqrt{k_{t}^{2}-4 N\left[\frac{B}{\beta A}\right]^{\frac{1}{\beta-1}}} .\right.
$$

Thus, the minimum aggregate capital stock which leads to an interior solution, $\bar{k}$, is

$$
\bar{k}=2\left[\frac{B}{\beta A}\right]^{\frac{1}{2(\beta-1)}} N^{\frac{1}{2}}
$$

in which case, according to (23), a half of capital is transferred from agriculture to industry and services, i.e., $\bar{k}^{a}=\bar{k}^{h}=\frac{1}{2} \bar{k}$. Under any $k_{t}>\bar{k}$, equation (22) has two different solutions, which are given by (23).

Summarizing, the equilibrium dynamics of our economy are described by the following system of two differential equations:

$$
\begin{gathered}
\dot{c_{t}}=\frac{c_{t}}{\gamma}\left[\beta A\left(k_{t}^{a}\right)^{\beta-1} N^{1-\beta}-\delta-\rho\right], \\
\dot{k_{t}}=A\left(k_{t}^{a}\right)^{\beta} N^{1-\beta}+B\left(k_{t}-k_{t}^{a}\right)^{2-\beta}-\delta k_{t}-c_{t},
\end{gathered}
$$

where $k_{t}^{a}$ can take three possible values, such as a corner solution $k_{t}$ and two interior solutions given by (23), provided that $k_{t}>\bar{k}$. Assuming that 
the economy sticks to the same solution during all its life, we obtain three possible equilibria.

Equilibrium I $\left(E_{I}\right)$ All production is concentrated in agriculture, and the production of industry and services is zero. The economy converges to a steady state $E_{I}^{*}$ with a zero growth rate,

$$
k_{I}^{a *}=\left(\frac{\delta+\rho}{A \beta}\right)^{1 /(\beta-1)} N \quad \text { and } \quad k_{I}^{h *}=0,
$$

where variables with stars and without time subscripts denote steady state values.

Equilibrium II $\left(E_{I I}\right) \quad$ All sectors produce non-zero output. The economy converges to a steady state $E_{I I}^{*}$ with a zero growth rate,

$$
k_{I I}^{a *}=\left(\frac{\delta+\rho}{A \beta}\right)^{1 /(\beta-1)} N \quad \text { and } \quad k_{I I}^{h *}=\left[\frac{\delta+\rho}{B}\right]^{\frac{1}{1-\beta}} \text {. }
$$

Equilibrium III $\left(E_{I I I}\right) \quad$ All sectors produce non-zero output, except of the limiting case $t \rightarrow \infty$, when the agricultural sector is closed down. The economy grows at an increasing growth rate, so that in the limit, we have ${ }^{6}$

$$
k_{I I I}^{a *}=0 \quad \text { and } \quad k_{I I I}^{h *}=\infty .
$$

The three equilibria constructed are shown in Figure 1. In fact, Equilibrium II is unstable to deviations that affect prices. This can be shown by

\footnotetext{
${ }^{6}$ Instead of an increasing growth rate, we can obtain an asymptotically constant growth rate by assuming a different function for externalities, one that satisfies $\lim _{k_{t} \rightarrow \infty} \varphi^{\prime}\left(k_{t}\right)=1$.
} 
Figure 1. Equilibria I, II and III and threshold value $\bar{k}$.

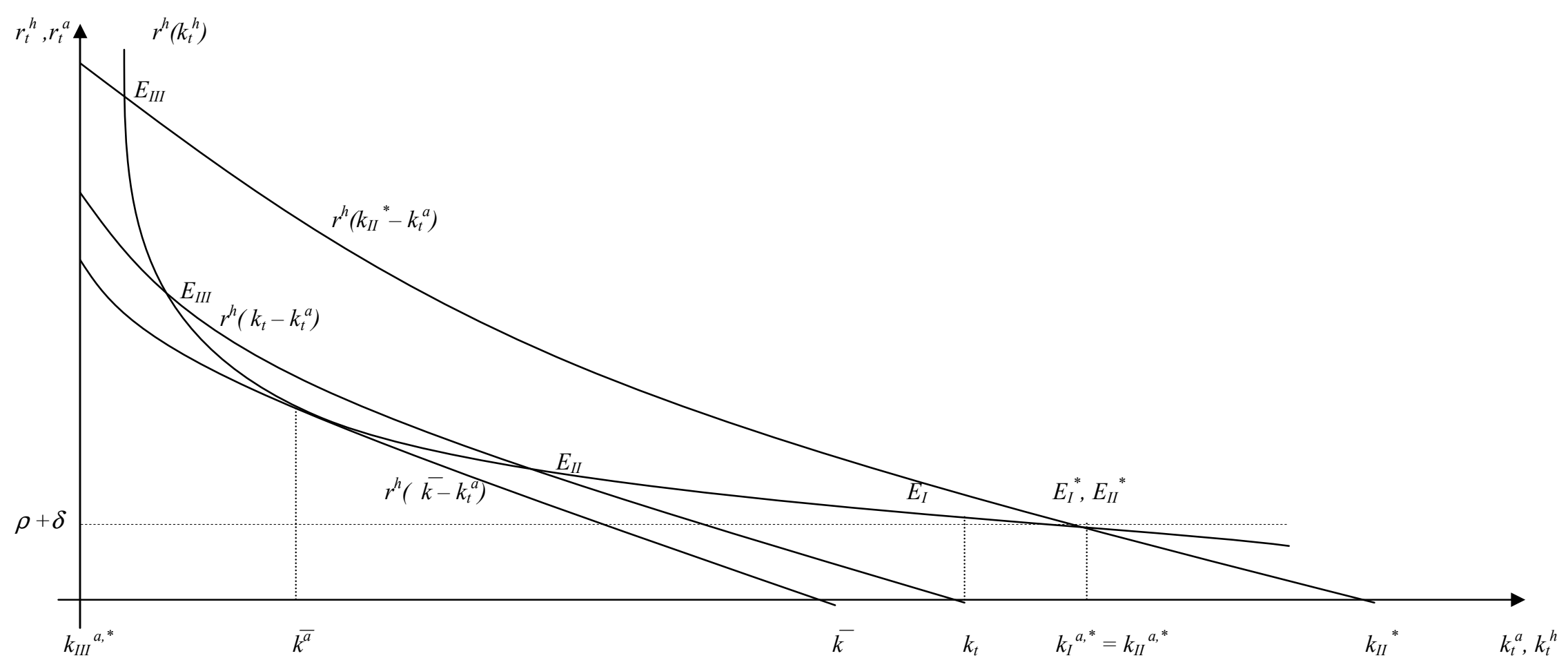


means of the Marshallian tatonnement argument, which is as follows. ${ }^{7}$ Suppose that all firms are situated in Equilibrium II but a coalition of firms with a positive measure deviates by investing more capital in agriculture than that implied by the Equilibrium II strategy. Then, as is seen from Figure 1, the marginal productivity of capital in agriculture becomes larger than that in industry and services, $r_{t}^{a}>r_{t}^{h}$, so that other firms start shifting capital from industry and services to agriculture until the economy ends up in Equilibrium I. Alternatively, if a group of firms with a positive measure deviates by investing more capital in industry and services than that implied by the Equilibrium II strategy, we have $r_{t}^{h}>r_{t}^{a}$, and all firms re-allocate capital from agriculture to industry and services until the economy ends up in Equilibrium III. ${ }^{8}$ In contrast, Equilibria I and III are stable to deviations. Consider, for example, Equilibrium I. If nobody invests in industry and services, the marginal productivity of these sectors is zero, $r_{t}^{h}=0$. Hence, $r_{t}^{a}>r_{t}^{h}$, and no firm has incentives to deviate from the equilibrium strategy, which is to invest all capital in agriculture. The same type of reasoning can be used to show the stability of Equilibrium III.

\footnotetext{
${ }^{7}$ See Matsuyama (1991) for a discussion.

${ }^{8}$ One can advocate Equilibrium II by arguing that it is stable under deviations that do not affect prices, i.e., deviations of one firm or a group of firms with a zero measure. It is also possible to make Equilibrium II stable to the price-affecting deviations by introducing adjustment costs as in Graham and Temple (2003). In this paper, we do not consider Equilibrium II as it is not relevant for the empirical issues we focus on.
} 


\section{Empirical evidence}

In this section, we discuss the empirical relevance of the model. As a first step, we shall summarize the model's testable implications. As we have shown in Section 3, in the presence of spillovers, we have two stable equilibria, and the model itself does not provide a way to discriminate between them. Which of the two equilibria prevails will depend on coordination of economic agents. According to our model, poor and slow-growing countries are those that are situated in Equilibrium I; such countries produce exclusively agricultural products. In turn, rich and fast-growing countries are those that are situated in Equilibrium III; such countries have a low (decreasing with time) share of agriculture and a high (increasing with time) share of industry and services.

To test the validity of these model's implications, we investigate the empirical relationship between the countries' sectorial composition and their economic performance. Our data come from the World Development Indicators CD-ROM (2000) data set. We distinguish the groups of 10 richest and 10 poorest countries in the sample by the level of GDP in 1999 and the group of 26 transition countries. (The countries entering each group are listed in the note ${ }^{b}$ of Table 1). In Figure 2, we plot the evolution of the GDP level, and the GDP and labor shares of agriculture, industry and services over the 
Table 1. The GDP level, and the GDP and labor shares of industry, agriculture and services: their evolution in the 26 transition countries and their averages in the 10 richest and the 10 poorest countries over 1990-1999.

\begin{tabular}{|c|c|c|c|c|c|c|c|}
\hline & $\begin{array}{l}\text { GDP } \times 10^{3}, \\
1995 U S \$\end{array}$ & $\begin{array}{l}\text { Agriculture, } \\
\% \text { of GDP }\end{array}$ & $\begin{array}{l}\text { Industry, } \\
\% \text { of GDP }\end{array}$ & $\begin{array}{l}\text { Services, } \\
\% \text { of GDP }\end{array}$ & $\begin{array}{l}\text { Agriculture, } \\
\% \text { of labor }\end{array}$ & $\begin{array}{l}\text { Industry, } \\
\% \text { of labor }\end{array}$ & $\begin{array}{l}\text { Services, } \\
\% \text { of labor }\end{array}$ \\
\hline \multicolumn{8}{|c|}{ The sample averages over 1990-1999 (transition countries excluded) } \\
\hline $\begin{array}{l}10 \text { richest } \\
\text { countries }\end{array}$ & $\begin{array}{l}32.8795 \\
(7.1379)\end{array}$ & $\begin{array}{c}3.8391 \\
(2.6883)\end{array}$ & $\begin{array}{l}27.8950 \\
(5.4049)\end{array}$ & $\begin{array}{l}68.2658 \\
(4.9883)\end{array}$ & $\begin{array}{c}5.5808 \\
(2.1626)\end{array}$ & $\begin{array}{l}27.9353 \\
(3.8329)\end{array}$ & $\begin{array}{l}66.4839 \\
(4.7026)\end{array}$ \\
\hline $\begin{array}{l}20 \text { richest } \\
\text { countries }\end{array}$ & $\begin{array}{l}27.3603 \\
(7.9113)\end{array}$ & $\begin{array}{c}3.1229 \\
(2.3510)\end{array}$ & $\begin{array}{l}27.7279 \\
(4.6484)\end{array}$ & $\begin{array}{l}69.1610 \\
(5.0275)\end{array}$ & $\begin{array}{c}4.9998 \\
(2.9741)\end{array}$ & $\begin{array}{l}28.2050 \\
(3.4645)\end{array}$ & $\begin{array}{l}66.7952 \\
(4.4666)\end{array}$ \\
\hline $\begin{array}{l}10 \text { poorest } \\
\text { countries }\end{array}$ & $\begin{array}{c}0.2091 \\
(0.0379)\end{array}$ & $\begin{array}{l}40.7081 \\
(6.7741)\end{array}$ & $\begin{array}{l}22.0963 \\
(9.4452)\end{array}$ & $\begin{array}{l}37.1956 \\
(9.5694)\end{array}$ & $\begin{array}{c}64.3617 \\
(24.4727)\end{array}$ & $\begin{array}{c}12.7633 \\
(13.2761)\end{array}$ & $\begin{array}{c}22.8750 \\
(14.7131)\end{array}$ \\
\hline $\begin{array}{l}20 \text { poorest } \\
\text { countries }\end{array}$ & $\begin{array}{c}0.2797 \\
(0.0855)\end{array}$ & $\begin{array}{l}37.1963 \\
(7.8396)\end{array}$ & $\begin{array}{l}22.4435 \\
(8.2681)\end{array}$ & $\begin{array}{l}40.3602 \\
(8.6807)\end{array}$ & $\begin{array}{c}63.4070 \\
(23.0161)\end{array}$ & $\begin{array}{c}11.8202 \\
(10.3214)\end{array}$ & $\begin{array}{c}24.7728 \\
(15.5285)\end{array}$ \\
\hline $\begin{array}{l}\text { Sample } \\
\text { average }\end{array}$ & $\begin{array}{c}7.8920 \\
(10.9282)\end{array}$ & $\begin{array}{c}17.0064 \\
(13.7608)\end{array}$ & $\begin{array}{l}29.7128 \\
(9.1682)\end{array}$ & $\begin{array}{c}53.2914 \\
(12.6647)\end{array}$ & $\begin{array}{c}28.3387 \\
(26.4523)\end{array}$ & $\begin{array}{l}22.3810 \\
(9.4071)\end{array}$ & $\begin{array}{c}49.4266 \\
(19.4702)\end{array}$ \\
\hline \multicolumn{8}{|c|}{ Transition countries } \\
\hline (1990 & $\begin{array}{c}2.9327 \\
(1.9869)\end{array}$ & $\begin{array}{l}19.9569 \\
(9.4173)\end{array}$ & $\begin{array}{l}44.3294 \\
(8.1943)\end{array}$ & $\begin{array}{l}35.7137 \\
(8.7523)\end{array}$ & $\begin{array}{c}25.6625 \\
(16.0007)\end{array}$ & $\begin{array}{l}34.7783 \\
(9.6604)\end{array}$ & $\begin{array}{l}42.0130 \\
(8.9955)\end{array}$ \\
\hline 1991 & $\begin{array}{c}2.6428 \\
(1.7830)\end{array}$ & $\begin{array}{c}19.9753 \\
(11.8047)\end{array}$ & $\begin{array}{l}43.1016 \\
(7.3116)\end{array}$ & $\begin{array}{c}36.9230 \\
(10.6059)\end{array}$ & $\begin{array}{c}21.2042 \\
(11.0089)\end{array}$ & $\begin{array}{c}35.8350 \\
(10.4385)\end{array}$ & $\begin{array}{l}42.9608 \\
(8.7966)\end{array}$ \\
\hline 1992 & $\begin{array}{c}2.3251 \\
(1.7268)\end{array}$ & $\begin{array}{c}20.2679 \\
(14.2351)\end{array}$ & $\begin{array}{l}39.9956 \\
(6.5374)\end{array}$ & $\begin{array}{c}39.7364 \\
(12.7310)\end{array}$ & $\begin{array}{c}21.5719 \\
(12.0169)\end{array}$ & $\begin{array}{c}33.8684 \\
(10.4514)\end{array}$ & $\begin{array}{l}44.5596 \\
(8.9684)\end{array}$ \\
\hline 1993 & $\begin{array}{c}2.2260 \\
(1.7946)\end{array}$ & $\begin{array}{c}18.7006 \\
(14.5371)\end{array}$ & $\begin{array}{l}38.2851 \\
(8.3876)\end{array}$ & $\begin{array}{c}43.0142 \\
(12.7510)\end{array}$ & $\begin{array}{c}22.0684 \\
(13.0334)\end{array}$ & $\begin{array}{l}33.3684 \\
(9.0204)\end{array}$ & $\begin{array}{l}44.5632 \\
(7.3505)\end{array}$ \\
\hline 1994 & $\begin{array}{c}2.1068 \\
(1.9042)\end{array}$ & $\begin{array}{c}19.9789 \\
(14.7155)\end{array}$ & $\begin{array}{l}35.2500 \\
(7.0487)\end{array}$ & $\begin{array}{c}44.7710 \\
(13.4273)\end{array}$ & $\begin{array}{c}22.7158 \\
(13.7967)\end{array}$ & $\begin{array}{l}31.9491 \\
(8.9616)\end{array}$ & $\begin{array}{l}45.3351 \\
(8.0711)\end{array}$ \\
\hline 1995 & $\begin{array}{c}2.0155 \\
(1.9829)\end{array}$ & $\begin{array}{c}20.6106 \\
(15.2225)\end{array}$ & $\begin{array}{l}34.0167 \\
(8.8889)\end{array}$ & $\begin{array}{c}45.3728 \\
(13.0781)\end{array}$ & $\begin{array}{c}24.0559 \\
(15.4856)\end{array}$ & $\begin{array}{l}29.6833 \\
(8.9327)\end{array}$ & $\begin{array}{l}46.2608 \\
(9.0788)\end{array}$ \\
\hline 1996 & $\begin{array}{c}2.0928 \\
(2.0626)\end{array}$ & $\begin{array}{c}19.3007 \\
(14.2974)\end{array}$ & $\begin{array}{c}33.3734 \\
(10.0355)\end{array}$ & $\begin{array}{c}47.3261 \\
(13.0308)\end{array}$ & $\begin{array}{c}24.6875 \\
(15.5073)\end{array}$ & $\begin{array}{l}28.6529 \\
(9.3386)\end{array}$ & $\begin{array}{l}46.9000 \\
(9.0647)\end{array}$ \\
\hline 1997 & $\begin{array}{c}2.1828 \\
(2.1621)\end{array}$ & $\begin{array}{c}18.7555 \\
(13.7277)\end{array}$ & $\begin{array}{l}32.3009 \\
(7.9561)\end{array}$ & $\begin{array}{c}48.9438 \\
(11.7312)\end{array}$ & $\begin{array}{c}23.5813 \\
(13.8756)\end{array}$ & $\begin{array}{l}28.3294 \\
(9.2467)\end{array}$ & $\begin{array}{l}48.2500 \\
(7.7793)\end{array}$ \\
\hline 1998 & $\begin{array}{c}2.2549 \\
(2.2399)\end{array}$ & $\begin{array}{c}17.3462 \\
(13.3492)\end{array}$ & $\begin{array}{l}31.7343 \\
(7.6277)\end{array}$ & $\begin{array}{c}50.9196 \\
(11.5368)\end{array}$ & $\begin{array}{c}23.2500 \\
(13.5619)\end{array}$ & $\begin{array}{l}27.7643 \\
(9.1741)\end{array}$ & $\begin{array}{l}48.9857 \\
(7.8726)\end{array}$ \\
\hline 1999 & $\begin{array}{c}2.3139 \\
(2.3236)\end{array}$ & $\begin{array}{c}16.9974 \\
(12.9314)\end{array}$ & $\begin{array}{l}31.1167 \\
(7.4356)\end{array}$ & $\begin{array}{c}51.8860 \\
(11.9705)\end{array}$ & - & - & - \\
\hline
\end{tabular}

Notes: ${ }^{\text {a }}$ Source: World Development Indicators CD ROM (2000).

${ }^{\mathrm{b}}$ The 10 richest countries are Switzerland, Denmark, Japan, Luxemburg, U.S., Netherlands, Norway, Iceland, Belgium and Austria (in descending order).

The 10 poorest countries are Burkina Faso, Madagascar, Rwanda, Chad, Nepal, Niger, Sierra Leona, Malawi, Burundi and Democratic Republic of Congo (in descending order).

The 26 transition countries are Albania, Armenia, Azerbaijan, Belarus, Bosnia and Herzegovina, Bulgaria, Croatia, Czech Republic, Estonia, Georgia, Hungary, Kazakhstan, Kyrgyz Republic, Latvia, Lithuania, Macedonia, Moldova, Poland, Romania, Russian Federation, Slovak Republic, Slovenia, Tajikistan, Turkmenistan, Ukraine and Uzbekistan (in alphabetic order).

${ }^{\mathrm{c}}$ Number in the table are sample averages and standard deviations of the corresponding variables. 
Figure 2. The GDP level, and the GDP and the labor shares of industry, agriculture and services: their evolution in 26 transition, 10 richest and 10 poorest countries over 1990-1999.
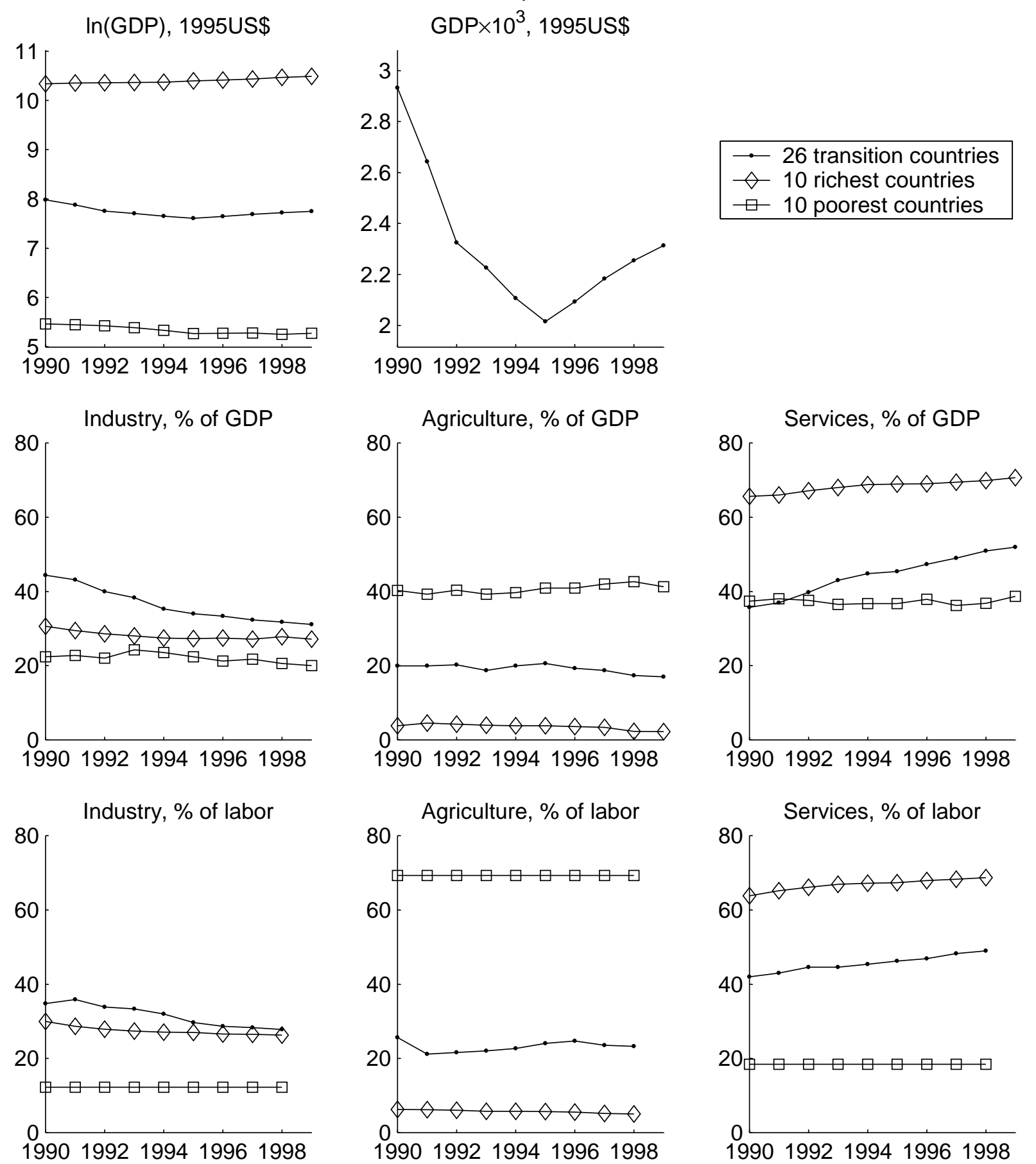

Note: For the 10 poorest countries, the labor shares are the averages of the corresponding variables over 1990-1999. 
1990-1999 period for the three groups distinguished, and in Figures 3, 4 and 5 , we plot the same time series for each of the transition countries considered. In Table 1, we provide the corresponding groups' statistics. To check the robustness of tendencies observed, in Table 1, we also report statistics for the groups of 20 richest and 20 poorest countries in the sample.

First of all, we see from Table 1 that there is an enormous difference in the level of economic development between our groups of 10 richest and 10 poorest countries, whose per-capita GDPs differ by a factor of more than 150 . Further, we observe a striking difference in the sectorial compositions between rich and poor economies. For example, for the 10 richest countries, the output (labor) share of agriculture is $3.6 \%(5.1 \%)$, the output share of industry is $27.9 \%(28.3 \%)$ and the output share of services is $68.5 \%(66.7 \%)$. In contrast, for the 10 poorest countries, the output (labor) share of agriculture is $41.1 \%(69.2 \%)$, the output share of industry is $19.7 \%(12.2 \%)$ and the output share of services is $39.2 \%(18.6 \%)$. That is, rich countries have a small agricultural sector and large industrial and service sectors, while poor countries have a large agricultural sector and small industrial and service sectors. According to our model, rich and poor countries are those that are situated in Equilibrium III and Equilibrium I, respectively, and we therefore conclude that the predictions of the model are consistent with the data. 
Figure 3. The evolution of GDP in the transition countries over 1990-1999.
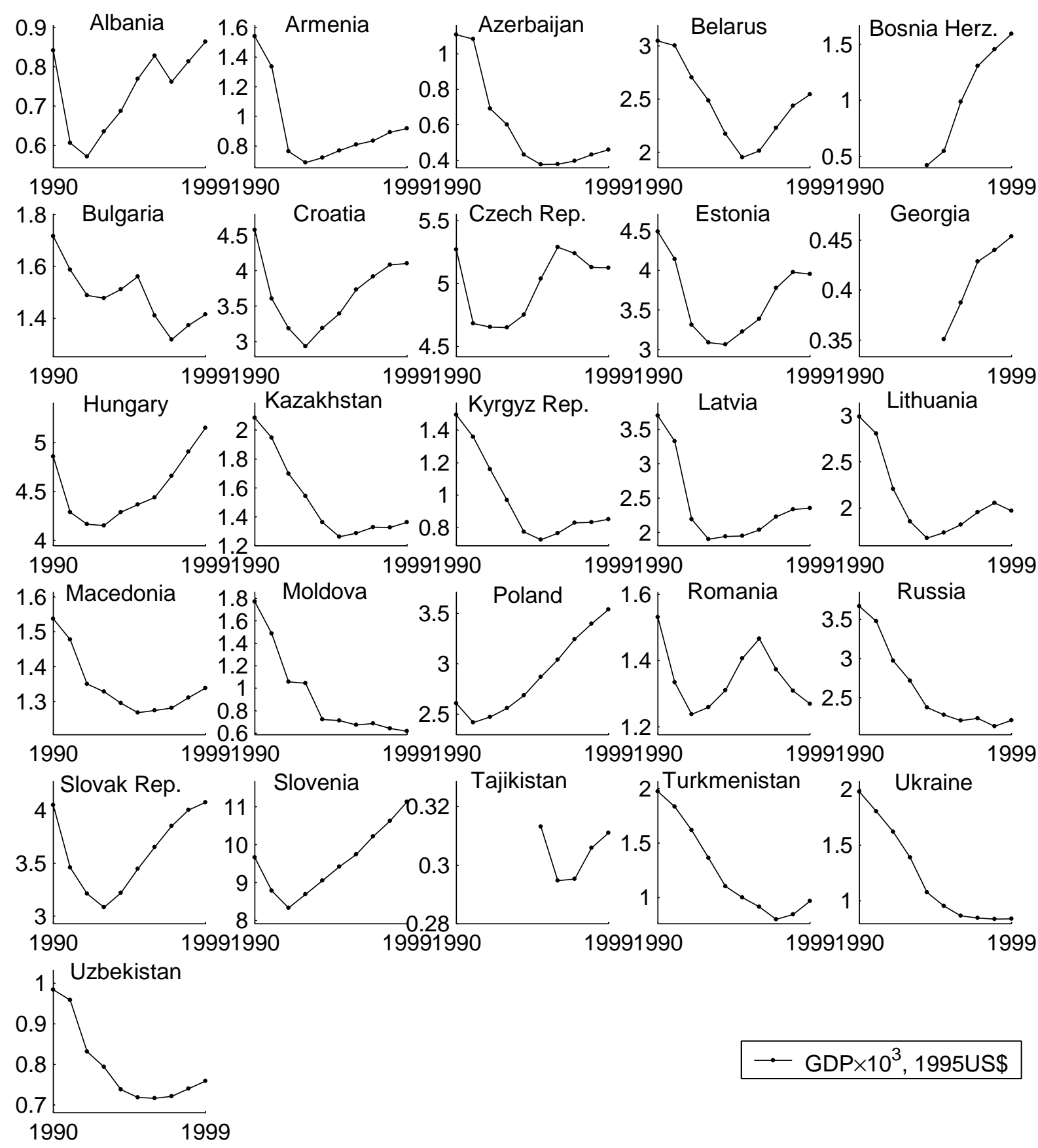
Figure 4. The evolution of the GDP shares of industry, agriculture and services in the transition countries over 1990-1999.
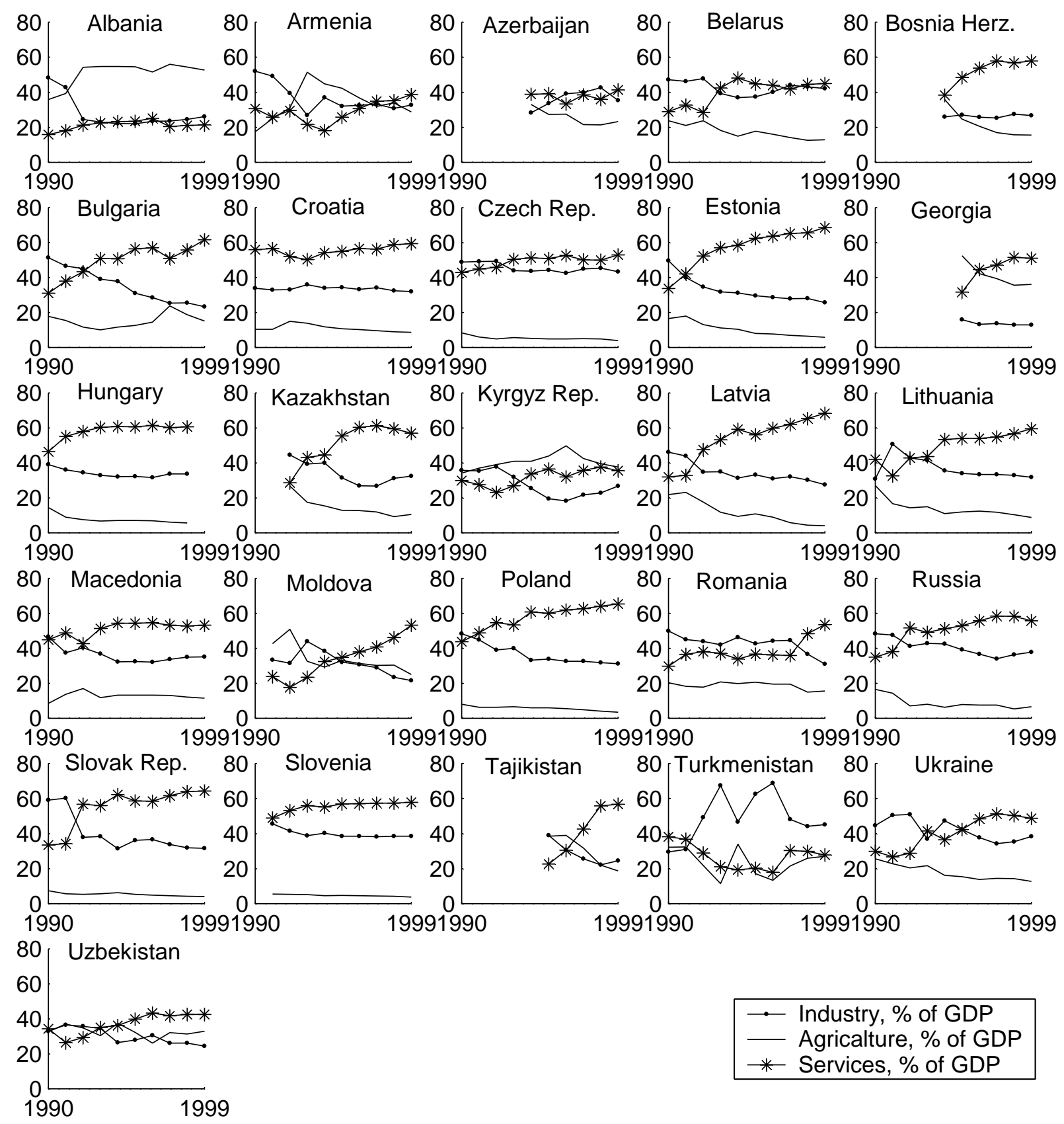
Figure 5. The evolution of the labor shares of industry, agriculture and services in the transition countries over 1990-1999.

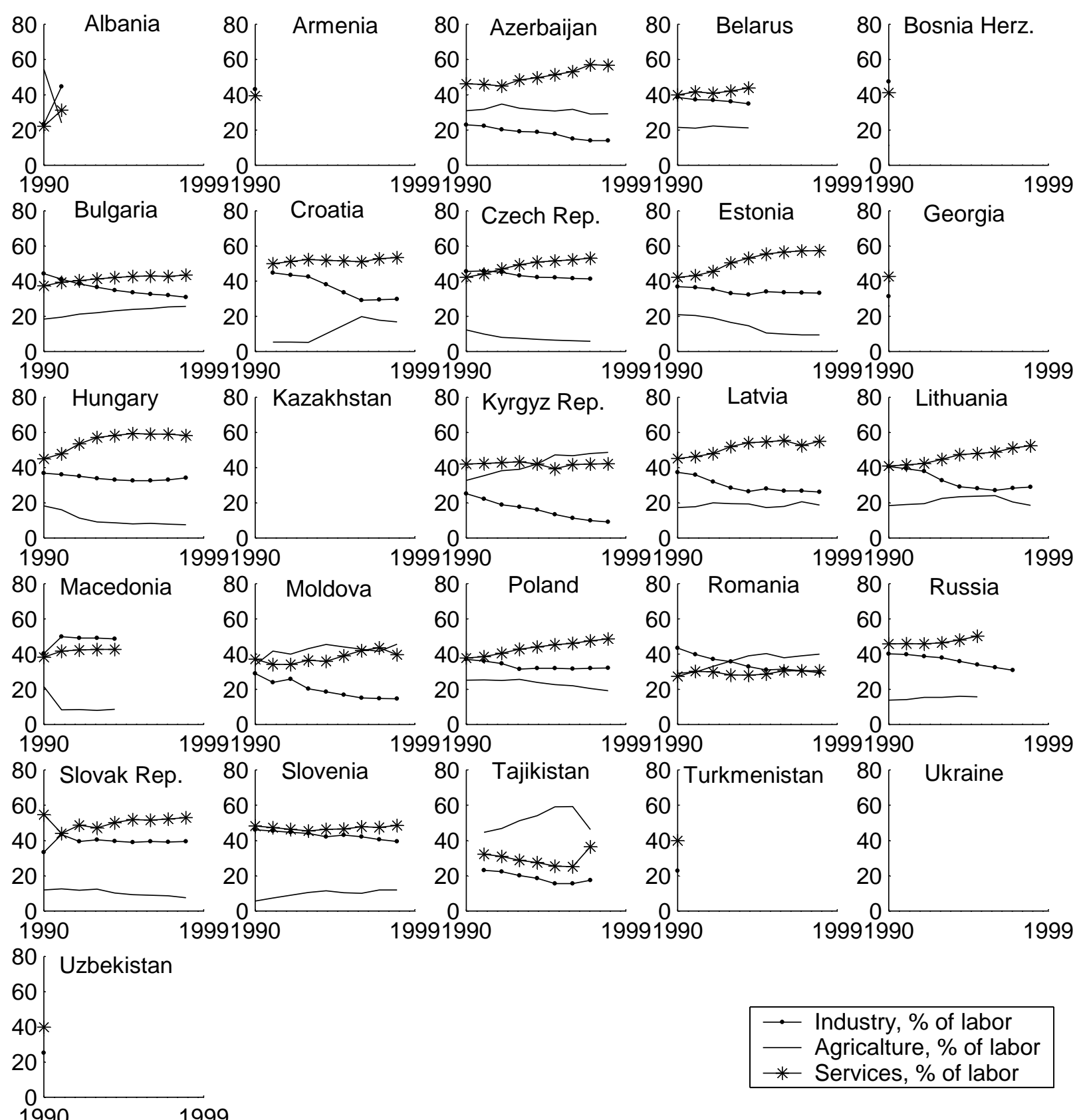


As far as the evolution of the sectorial composition is concerned, it is well-known that the currently rich countries have experienced a dramatic decline in the output share of agriculture and an increase in the output shares of industry and services over the process of economic development. In contrast, the sectorial composition of the currently poor countries have been stable during a relatively long period. For the corresponding evidence, see, e.g., Kongsamut, Rebelo and Xie (1997), Hansen and Prescott (2000). Thus, our model can successfully account not only for the differences in the development patterns observed across rich and poor countries but also for time-series patterns of economic development of rich and poor countries.

We shall now turn to transition countries, which are the main subject of our investigation. When the Soviet system was broken down and transition to market economy began, the former Soviet countries were roughly in the middle between rich and poor countries. In 1990, the average transition country had per-capita GDP, which was about 10 times smaller than that of 10 richest countries but which was about 10 times larger than that of 10 poorest countries. As far as the sectorial composition of transition economies is concerned, it was artificially created under the Soviet central-planning system, and it was not typical for either rich or poor market economies. In 1990, the average transition country had a very large industrial sector with 
the output (labor) share of $44.3 \%(34.8 \%)$, a relatively small service sector with the output (labor) share of $35.7 \%(42.0 \%)$ and a medium agricultural sector with the output (labor) share of $20.0 \%$ (25.7\%).

There is one question concerning the transition countries, which is of much interest to address in the context of our model, namely: "Where do the transition countries transit now, to rich or poor countries?" Indeed, according to our model, each country can become either rich or poor depending on which equilibrium it coordinates on. Therefore, our next step will be to use the available empirical evidence in order to establish which of the two equilibria the transition countries have selected.

The tendencies in Table 1 and Figures 2 and 3 about the output dynamics in the transition countries are not entirely conclusive in this respect. Most of the transition countries experienced a $J$-curve output pattern over the 19901999 period: in 1990, the average per-capita GDP of the transition countries expressed in constant 1995 \$US was 2932.7; in 1995, it reached a minimum of 2015.5; and in 1999, it rose to 2313.9. Although during the last years, the transition countries exhibit an upward trend in the per-capita GDP, it is not yet clear whether such a trend is a result of a recovery after the crisis or it is an indication of having jumped to a stable growth path. In fact, most of the transition countries still have not reached the output level which they had at 
the beginning of transition.

We now focus on the evolution of the sectorial composition of the transition countries. Recall that according to our model, an economy situated in the good equilibrium (Equilibrium III) has the agricultural sector decreasing over time, and it has the industrial and service sectors increasing over time, with the latter two sectors being in a fixed proportion given by (18). Since the former Soviet countries had excessively large industrial sectors and excessively small service sectors relative to the corresponding sectors in rich countries, in the good equilibrium, the transition countries should decrease both the industrial and agricultural sectors and they should increase the service sector. On opposite, in a bad equilibrium (Equilibrium I), the transition countries should increase the agricultural sector and decrease both the industrial and service sectors. In our simple setup, a reallocation of capital from one sector to another is costless, and thus, all changes in the sectorial composition can take place instantaneously. In a more realistic model with adjustment costs, the changes in the sectorial composition will be subject to some inertia. Thus, we should not take the model's prediction about the instantaneous adjustment literally but rather try to see whether the evolution of the sectorial composition in the transition countries is consistent with Equilibrium I or Equilibrium III. 
As is seen from Table 1, during the 1990-1999 period, the output shares of the industrial and the agricultural sectors in the transition countries reduced from $44.3 \%$ to $31.1 \%$ and from $20.0 \%$ to $17.0 \%$, respectively, and the output share of the service sector increased from $35.7 \%$ to $51.9 \%$. Similar regularities hold for the changes in the distribution of the labor force across sectors: the labor shares of the industrial and the agricultural sectors reduced from $34.8 \%$ to $27.8 \%$ and from $25.7 \%$ to $23.2 \%$, respectively, while the labor share of the service sector increased from $42.0 \%$ to $49.0 \%$. Thus, there is strong evidence that the sectorial composition of the transition countries as a group converges to that of rich rather than poor countries.

We finally look at the evolution of the sectorial composition for each individual country in the transition group. Notice that the sectorial output shares in Figure 4 do not always expose the same tendencies as do the sectorial labor shares in Figure 5, which is because the former shares are influenced by changes in the relative productivity of sectors. Nonetheless, for such countries as Czech Republic, Estonia, Lithuania, Hungary, Poland and Slovak Republic, the pattern implied by Equilibrium III is well seen for both the output and the labor shares, and their sectorial composition currently approaches the one of the 10 richest countries. In fact, these transition countries are ones that do best in economic terms. On the contrary, the tran- 
sition countries doing poorly have experienced the changes in their sectorial composition that put them closer to poor than to rich countries. According to the output-shares figure, Albania significantly increased the agricultural sector; Turkmenistan both increased the industrial sector and decreased the service sector; and such countries as Armenia, Azerbaijan, Kyrgyz Republic and Uzbekistan exhibited changes in their sectorial composition that lack a definite pattern. In turn, as follows from the labor-shares figure, such countries as Bulgaria, Croatia, Kyrgyz Republic, Moldova, Romania and Tajikistan expanded their agricultural sector. In the case of Bulgaria and Croatia, we also observe an expansion of the service sector but such an expansion is not sufficient to absorb all labor exiting the industrial sector. The agricultural growth in Kyrgyz Republic, Moldova, Romania and Tajikistan is more worrying in a sense that it was not accompanied by visible growth of the service sector and hence, it may indicate that those countries move to the bad equilibrium.

\section{Conclusion}

This paper presents a general equilibrium three-sector growth model, in which the agricultural sector has constant returns to scale, while the industrial and the service sectors have increasing returns to scale. The presence 
of economies of scale in our model leads to multiplicity of equilibrium. Our model predicts that rich and fast-growing countries are ones that are situated in the good equilibrium: such countries experience non-vanishing growth, they reduce agriculture, and increase industry and services over time. In turn, poor and stagnating countries are ones that are situated in the bad equilibrium: they have no long-run growth and specialize in the naturalresource-based agriculture. In our setup, each country can become rich and fast-growing if economic agents manage to coordinate on the good equilibrium.

Our model provides a framework for analyzing the development experience of the transition countries. It predicts that if the transition countries move to the rich world, we should see a reallocation of resources from industry and agriculture to services, whereas, if they move to the poor world, we must observe an expansion of agriculture. Our empirical analysis suggests that overall, the transition countries move to the good equilibrium. This is undoubtfully true for the most developed countries in the transition sample such as Czech Republic, Estonia, Lithuania, Hungary, Poland and Slovak Republic, whose sectorial composition is now close to that of the world richest countries. However, for less developed transition countries, the development pattern is not entirely clear. In particular, such countries as Albania, 
Armenia, Azerbaijan, Kyrgyz Republic, Moldova, Romania, Tajikistan and Uzbekistan have experienced growth of the agricultural sector, which can be viewed as an indication of being in the bad equilibrium.

\section{References}

[1] Atkeson, A. and P. Kehoe, 2000, Paths of development for early- and late-bloomers in a dynamic Heckscher-Ohlin model, Federal Reserve Bank of Minneapolis, Research Department Staff Report 256.

[2] Choi, J. and E. Yu, 2002, External economies in the international trade theory: a survey, Review of International Economics 10, 708-728.

[3] Eswaran, M. and A. Kotwal, 2002, The role of the service sector in the process of industrialization, Journal of Development Economics 68, 401-420.

[4] Guilló, M. and F. Pérez, 2003, The curse and blessing of fixed specific factors in small open economies, IVIE WP-AD 2003-36.

[5] Graham, B. and J. Temple, 2003, Rich nations, poor nations: How much can multiple equilibria explain? manuscript.

[6] Hansen, G. and E. Prescott, 2002, Malthus to Solow, American Economic Review 60, 895-911.

[7] Kemp, M. and A. Schweinberger, 1991, Variable returns to scale, nonuniqueness of equilibrium and the gains from international trade, Review of Economic Studies 58, 807-816.

[8] Kongsamut, P., S. Rebelo and D. Xie, 1997, Beyond balanced growth, NBER Working Paper 6159.

[9] Matsuyama, K., 1991, Increasing returns, industrialization and indeterminacy of equilibrium, Quarterly Journal of Economics 106, 617-650.

[10] Matsuyama, K., 1992, Agricultural productivity, comparative advantage, and economic growth, Journal of Economic Theory 58, 317-334.

[11] Murphy, K., A. Schleifer and R. Vishny, 1989, Industrialization and the big push, Journal of Political Economy 97, 1003-1026. 
[12] Rodrik, D., 1996, Coordination failures and government policy: a model with application to East Asia and Eastern Europe, Journal of International Economics 40, 1-22.

[13] Rodrik, D., 2003, Growth strategies, In: P. Aghion and S. Durlauf, Eds., Handbook of Economic Growth, Ch. 5.

[14] Romer, P., 1986, Increasing returns and long-run growth, Journal of Political Economy 94, 1002-1037.

[15] Ventura, J., 1997, Growth and interdependence, Quarterly Journal of Economics 112, 57-84. 